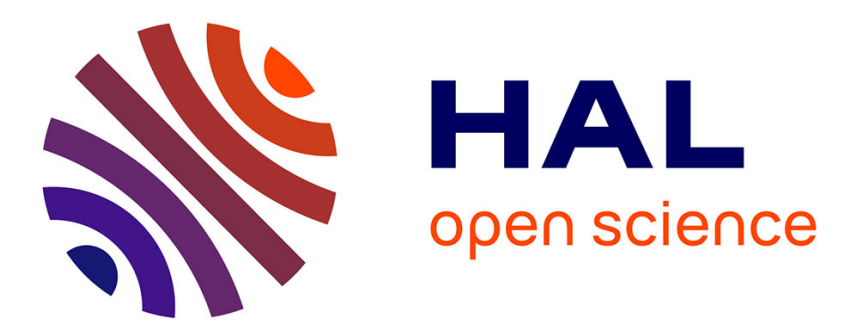

\title{
Dendrochemistry of Multiple Releases of Chlorinated Solvents at a Former Industrial Site
}

Jean-Christophe Balouet, Joel G Burken, Franck Karg, Don Vroblesky, Kevin T Smith, Hakan Grudd, Anders Rindby, Francois F. Beaujard, Michel Chalot

\section{- To cite this version:}

Jean-Christophe Balouet, Joel G Burken, Franck Karg, Don Vroblesky, Kevin T Smith, et al.. Dendrochemistry of Multiple Releases of Chlorinated Solvents at a Former Industrial Site. Environmental Science and Technology, 2012, 46 (17), pp.9541-9547. 10.1021/es300318v . hal-00821404

\section{HAL Id: hal-00821404 https://hal.science/hal-00821404}

Submitted on 28 May 2020

HAL is a multi-disciplinary open access archive for the deposit and dissemination of scientific research documents, whether they are published or not. The documents may come from teaching and research institutions in France or abroad, or from public or private research centers.
L'archive ouverte pluridisciplinaire HAL, est destinée au dépôt et à la diffusion de documents scientifiques de niveau recherche, publiés ou non, émanant des établissements d'enseignement et de recherche français ou étrangers, des laboratoires publics ou privés. 


\title{
Dendrochemistry of Multiple Releases of Chlorinated Solvents at a Former Industrial Site
}

\author{
Jean Christophe Balouet, ${ }^{* \dagger}$ Joel G. Burken, ${ }^{\ddagger}$ Frank Karg, ${ }^{\S}$ Don Vroblesky, ${ }^{\Perp}$ Kevin T. Smith, ${ }^{\perp}$ \\ Håkan Grudd," Anders Rindby, ${ }^{\text {II }}$ François Beaujard, ${ }^{\nabla}$ and Michel Chalot ${ }^{\mathrm{O}}$ \\ ${ }^{\dagger}$ Environment International, 2 ruelle du Hamet, 60129 Orrouy, France \\ ${ }^{\ddagger}$ Missouri University of Science and Technology, Rolla, Missouri 65409, United States \\ ${ }^{\S}$ HPC R\&D Division, Noyal-Chatillon, France \\ "U.S. Geological Survey, Columbia, South Carolina 29210, United States \\ ${ }^{\perp}$ Northern Research Station, USDA Forest Service, 271 Mast Road, Durham, New Hampshire 03824, United States \\ ${ }^{\#}$ Bert Bolin Centre for Climate Research, Department of Physical Geography and Quaternary Geology, Stockholm University, SE-106 \\ 91 Stockholm, Sweden \\ IICox Analytical Systems, Sweden \\ ${ }^{\nabla}$ UMR 547 - PIAF, INRA-Université Blaise Pascal, INRA Centre de Clermont-Ferrand, Site de Crouel -234, Avenue du Brézet, 63100 \\ Clermont-Ferrand cedex 02, France \\ OLaboratory Chrono-environnement, Franche-Comté University, UMR6249, Place Leclerc, 25030 Besançon, France \\ Tree/Microbe Interaction Unit, Faculty of Sciences and Technology, Lorraine University, UMR 1136, 54506 Vandoeuvre cedex, \\ France
}

ABSTRACT: Trees can take up and assimilate contaminants from the soil, subsurface, and groundwater. Contaminants in the transpiration stream can become bound or incorporated into the annual rings formed in trees of the temperate zones. The chemical analysis of precisely dated tree rings, called dendrochemistry, can be used to interpret past plant interactions with contaminants. This investigation demonstrates that dendrochemistry can be used to generate historical scenarios of past contamination of groundwater by chlorinated solvents at a site in Verl, Germany. Increment cores from trees at the Verl site were collected and analyzed by energy-dispersive X-ray fluorescence (EDXRF) line scanning. The EDXRF profiles showed four to six time periods where tree rings had anomalously high concentrations of chlorine $(\mathrm{Cl})$ as an indicator of potential contamination by chlorinated solvents.

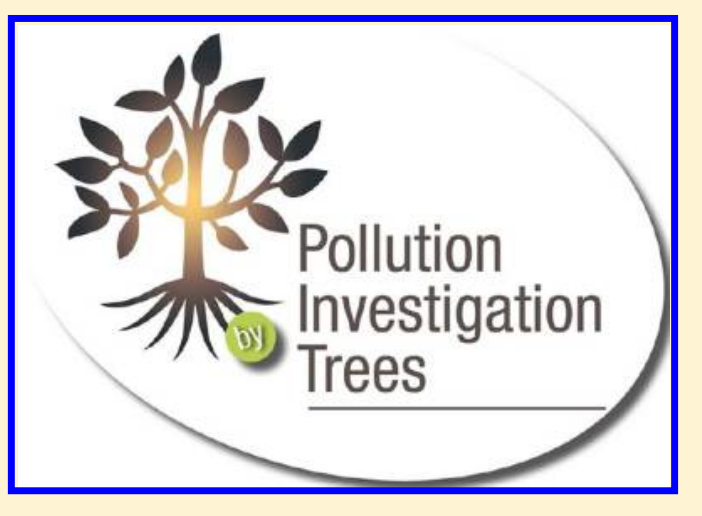

\section{INTRODUCTION}

Annual growth rings can preserve past environmental changes within the biological requirements of tree survival. ${ }^{1,2}$ The relationship of one ring representing 1 year of tree growth was recognized by Theophrastus in ancient Greece, ${ }^{3}$ and Leonardo da Vinci $^{4}$ in Renaissance Italy acknowledged year-to-year changes in rings as being related to climatic changes. The assignment of absolute calendar dates for the year of wood formation, the hallmark of dendrochronology, enables the dating of wood samples and artifacts as long as an unbroken record from the current time exists. ${ }^{5}$ Chiment and Chiment ${ }^{6}$ reviewed over 300 research articles on dendrochemical records derived from elemental isotopes covalently bound to wood constituents; essential "fertilizer elements" associated with ionexchange sites in wood such as nitrogen $(\mathrm{N})$, potassium $(\mathrm{K})$, and magnesium $(\mathrm{Mg})$; semivolatile or volatile organic compounds, including halogenated volatile organic compounds (SVOCs, VOCs, and HVOCs, respectively). Inferring changes in the external environment from dendrochemical patterns requires an understanding of tree biology, tree physiology, and tree infections. ${ }^{7}$ Dendrochemical interpretations are strengthened when combined with traditional analyses of wood chemistry and dendrochronology and can be used effectively to date environmental events.

Dendrochemistry, the chemical analysis and interpretation of precisely dated tree rings, can provide a date-specific record of chemical changes ${ }^{8,9}$ and expands on phytoscreening, in which the chemical analysis of plants is used to monitor and detect plant-chemical exposure. ${ }^{10}$ Phytoscreening methods have documented the presence of contaminants or their metabolic products from chlorinated solvents and fossil fuels. ${ }^{11}$ When

Received: January 25, 2012

Revised: July 26, 2012

Accepted: August 2, 2012

Published: August 2, 2012 
combined, phytoscreening and dendrochemical investigation can increase the understanding of current and past environmental events, termed phytoforensics. ${ }^{10}$ Dendrochemistry can indicate a chemical change in the annual rings, and this information can be combined with groundwater data and modeling, knowledge of contaminant source type and location, and knowledge of tree species physiology to collectively generate scenarios of past events leading to contaminant release and transport and also potential exposure pathways.

Dendrochemistry has successfully utilized several analytical techniques. Examples include energy-dispersive X-ray fluorescence (EDXRF), proton-induced X-ray emission (PIXE), analysis of wood extracts or digests (e.g., inductively coupled plasma-mass spectroscopy, or ICPMS), and atomic emission spectroscopy (AES). EDXRF methods tend to be favored largely because of the capacity for simultaneous analysis of 31 target or marker elements and compounds at a high spatial resolution of $50 \mu \mathrm{m}$ across the tree-ring sample. ${ }^{6,12}$ Regardless of analytical method, it is important that the dendrochemist determine which observations are related to processes involved with tree physiology and species relative to the interaction with pollutants. $9,12,13$

In this study, we describe the dendrochemical investigation methods and results in a groundwater pollution case, where the tree chemistry appears to reflect four to five asynchronous releases of HVOCs, along with other environmental influences and physiological anomalies. For this study, four trees were used that were located along a plume (see Figures 1-5). These trees (see Table 1) belong to three genera (two oaks, one sycamore, and one fir).

Table 1. Tree Species Sampled for Dendrochemical Analysis in Verl, Germany

\begin{tabular}{|c|c|c|c|}
\hline $\begin{array}{l}\text { tree } \\
\text { number }\end{array}$ & tree species & $\begin{array}{l}\text { oldest } \\
\text { ring }\end{array}$ & years of unique $\mathrm{Cl}$ anomalies \\
\hline 2 & Quercus sp. & 1896 & $\begin{array}{l}1948 / 1949,1961,1987,1997 \text {, } \\
2002\end{array}$ \\
\hline 5 & Quercus sp. & 1978 & 1989, 2000 \\
\hline 6 & $\begin{array}{l}\text { Platanus } \\
\text { occidentalis }\end{array}$ & 1983 & 1993, 1996 \\
\hline 7 & Abies sp. & 1975 & 1980, 1990, 1995, 2004 \\
\hline
\end{tabular}

\section{EXPERIMENTAL SECTION}

Study Area. Verl is a relatively small city in Germany with an area of $73 \mathrm{~km}^{2}$ and a population of about 25000 . The aquifer at Verl consists of heterogeneous glacial deposits, resulting in uncertainties in determining the aquifer characteristics. The aquifer contains an elongated plume of groundwater contaminated by chlorinated aliphatic solvents (Figure 1). An earlier investigation using phytoscreening methods demonstrated that the trees take up groundwater contamination and could be used to map the plume. ${ }^{10,14}$ The dominant contaminants in the groundwater are tetrachloroethene (PCE), trichloroethene (TCE), and cis-1,2-dichloroethene ( $c \mathrm{DCE})$. TCE and $c \mathrm{DCE}$ are known to be dechlorination products of PCE. Much of the contamination is believed to originate from a former mechanical plant that used PCE in dipping baths from 1948 to 1969 (Figure 1). Groundwater contamination by PCE was discovered in 1972. Up-filling of PCE drums continued in the 1970s, and a private garage shop that operated at the site between 1980 and 1999 also used PCE. Phytoscreening was successfully used to map the configuration

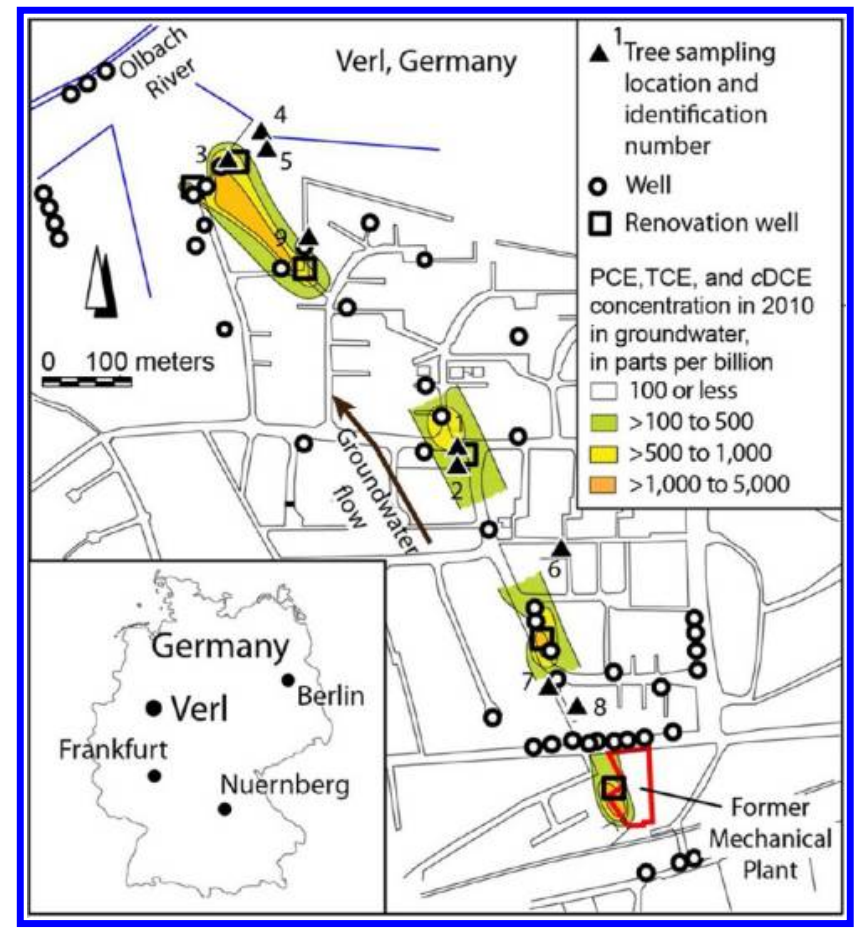

Figure 1. Location of study area, groundwater sampling, and trees sampled for dendrochemistry in 2010. Groundwater concentrations were measured in 2010 by the consulting firm HPC Envirotec. The plume map used in figure is for the total of PCE, TCE and $c$ DCE.

of the chlorinated solvent plume of groundwater. ${ }^{10,14}$ The phytoscreening analysis also provided evidence of multiple TCE sources, subsequently supported by the discovery that fill material at the site was also contaminated by HVOCs. ${ }^{14}$

Sample Preparation. Increment cores $(10 \mathrm{~mm}$ in diameter) were extracted from nine trees (Figures 1 and 2)

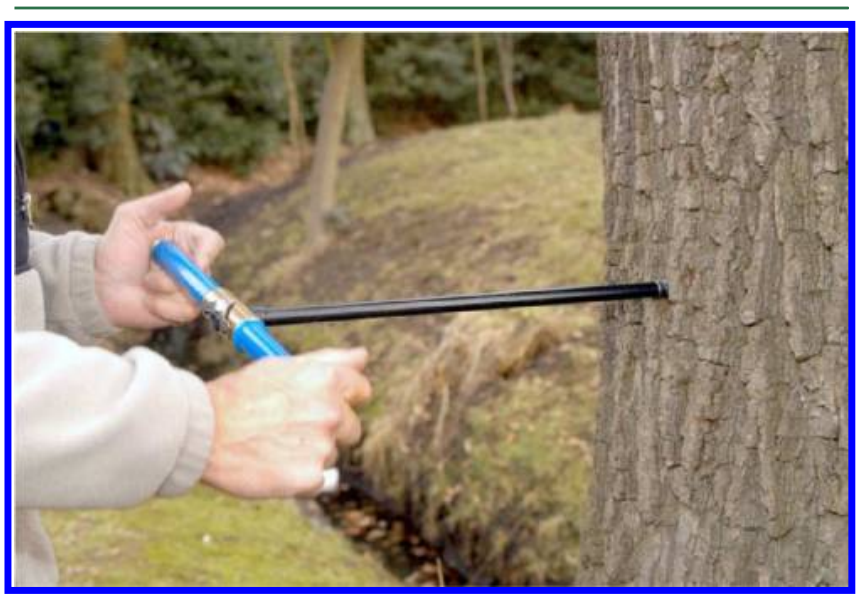

Figure 2. Sampling of tree 2 using a 10-mm Pressler borer.

on February 22, 2010. After 5 days of drying in ambient air between grooved wooden blocks, cores were surfaced with a graded series of silicon carbide sandpapers $(50,100,200$, and 400 grit). The sanded cores were observed under a digital microscope (40-100× magnification) to evaluate the presence of branch anomalies, infection, and tree response to injury and infection that could have affected the dendrochemical pattern. Cores extracted from trees 2, 5, 6, and 7 passed the preliminary screening and were analyzed by EDXRF at Dendrolab, 
Stockholm University, using an Itrax Multiscanner (www. coxsys.se). All sample processing and EDXRF analyses were conducted under conditions of constant air temperature (20 ${ }^{\circ} \mathrm{C}$ ) and relative humidity (50\%). The sample cores were first cut along their full length parallel to the transverse wood surface with a twin-blade saw to produce 2 -mm-thick laths with planar surfaces. The laths were then mounted vertically in the Itrax Multiscanner to allow for radiographic density and EDXRF analyses along the length of the planar transverse surface of the samples.

EDXRF Analysis. The Itrax Multiscanner is a "flat-beam" Xray scanner where samples are exposed to a precisely defined, thin X-ray beam with a vertical dimension of $50 \mu \mathrm{m}$. An X-ray line camera records the transmitted radiation that passes through the sample. Hence, a full-scale two-dimensional radiographic image with $50-\mu \mathrm{m}$ resolution is obtained by moving the sample relative to the beam in $50-\mu \mathrm{m}$ steps. At each step, a silicon drift chamber detector (SDD) records the characteristic fluorescent X-ray radiation (XRF) from specific alkaline earth and other metal elements with the atomic weight of $\mathrm{Mg}$ and higher. The collimator system within the SDD confines XRF recording to a sample area of $0.05 \times 2 \mathrm{~mm}^{2}$. The SDD functions as an energy-dispersive $\mathrm{X}$-ray detector, with a capacity of 100000 counts per second (cps) and a resolution of about $135 \mathrm{eV}$ at $5.9 \mathrm{keV}$. Equipped with the standard 1.9-kW chromium-tube X-ray source, the SDD records about $20000 \mathrm{cps}$ for wood tissue. An exposure time of $10 \mathrm{~s}$ is normally sufficient to record element concentrations above $10 \mathrm{ppm}^{15}$

With the resolution of $50 \mu \mathrm{m}$, a tree ring with a width of 1 $\mathrm{cm}$ provides $200 \mathrm{XRF}$ data points for elemental concentrations. High-resolution profiles of elemental concentrations were established over a large number of rings within a few hours (about $3.3 \mathrm{~min} / \mathrm{mm}$ ) and in a nondestructive way. The raw EDXRF data, made available as an Excel file, provide relative concentrations in counts for 31 elements along with physical parameters (locations, counts, mean squared errors). The raw data were computerized using an xls template, called Scanchem, that automatically generates density-corrected concentrations and time-weighted centered moving averages (TWCMAs). ${ }^{9,12}$

Influences on Tree Chemistry. Dendrochemical profiles can have characteristic intra-ring patterns that show some level of annual repetition. In this study, dendrochemical anomalies are considered to be parts of the tree core where the chemical concentration differs from the characteristic pattern by at least $30 \%$ of the regular concentration minima, maxima, or annual averages, extending over one or more rings. In the Verl study, the anomalies represent time periods when relatively large amounts of chloride were taken up by the trees.

A variety of factors can cause differential annual uptake of solutes, including differences in rainfall, depth to groundwater or contaminants, locations of the root systems, and groundwater solute concentrations. During years with comparatively large amounts of rainfall, trees are likely to contain lower concentrations of groundwater constituents, such as contamination, because the roots intercept infiltrating rainwater. In addition, local recharge to the aquifer dilutes the shallow groundwater and can force plumes into deeper zones where they are farther from the root system. Differences in annual precipitation can also influence the position of the root system. The optimum root depth for most hardwood trees in areas of shallow groundwater is neither submerged beneath the water table nor out of reach of the capillary fringe. In areas such as at tree 2 where the groundwater is only about $50 \mathrm{~cm}$ below the land surface, it is possible that even small changes in the watertable depth could result in some level of root adjustment by the trees. Adjustment of root location also can occur to position the roots in a less toxic zone, which can result in a shift in the zone from which the plant derives water (root avoidance and microroot turnover). The historical groundwater contaminant concentrations are not known, but the presence of greater than $1000 \mathrm{ppb}$ of HVOCs at the downgradient part of the plume (Figure 1) and evidence of HVOC decay (dechlorination products) imply that historical concentrations might have been substantially higher than are now. Thus, root avoidance issues also might have occurred. Therefore, the chemical signature in tree rings from groundwater contamination could change from year to year.

Some natural events are known to leave characteristic dendrochemical signatures, such as calcium ( $\mathrm{Ca}$ ), $\mathrm{Mg}$, and $\mathrm{K}$ for infections, including those introduced by wounds from pruned and naturally shed branches; ${ }^{7}$ and zinc $(\mathrm{Zn})$ and iron $(\mathrm{Fe})^{16}$ or $\mathrm{Ca}, \mathrm{Mg}$, and manganese $(\mathrm{Mn})^{17}$ for soil acidification. Similarly, pollution effects can have characteristic dendrochemical fingerprints. ${ }^{7}$ For example, a dendrochemical anomaly from dechlorination of chlorinated solvents might be expected to consist only of $\mathrm{Cl}$, whereas a dendrochemical anomaly from road salt might consist of increased concentrations of multiple common constituents of road salt. Additional constituents besides $\mathrm{Cl}$ that might be present in groundwater affected by road salt include sulfur (S), K, and Ca. $\mathrm{S}$ and $\mathrm{Cl}$ can be associated with fossil fuels, and petroleum fuels can be associated with trace metals such as vanadium (V) or nickel $(\mathrm{Ni})$, versus lead $(\mathrm{Pb})$ for leaded gasoline. Fertilizers contain phosphorus (P) and $\mathrm{K},{ }^{7}$ and groundwater affected by sewage leakage can be characterized by elevated P. EDXRF analysis provides the capability to analyze for these constituents in tree cores on a sub-ring scale, potentially allowing interpretation of the environmental or physiological events associated with the ring chemistry.

For the Verl site, $\mathrm{Cl}$ associated with chlorinated solvent degradation was used as a monoelemental marker that was detectable by XRF. ${ }^{12}$ HVOCs are naturally degraded by bacteria within groundwater and soils in reducing environments in reductive dechlorination or "dehalorespiration" (i.e., PCE to TCE to $c \mathrm{DCE}$ ) and can generate large plumes of $\mathrm{Cl}$ ions that can be taken up by root systems of trees. ${ }^{18,19}$ The parent HVOC can also be taken up by trees. HVOCs within trees can spread through the porous wood ${ }^{20}$ and can partly evaporate through the stem ${ }^{21}$ and leaf crown. ${ }^{22}$ HVOCs can also degrade in plant tissues if reducing conditions dominate (i.e., in a decaying tree) or through aerobic plant defense pathways to form trichloroacetic acid and other metabolites that can be further degraded. ${ }^{23,24}$

At relatively low concentrations, $\mathrm{Cl}$ is usually stable in woody tissues after fixation, presumably through ionic binding, and is not readily remobilized/retranslocated., ${ }^{9}$ The potential for HVOC movement across ring boundaries and for HVOC dechlorination within trees leads to the possibility that $\mathrm{Cl}$ generated from in-tree degradation might be fixated in growth rings not corresponding to the year of HVOC uptake. In situations where there is no substantial dechlorination activity in the groundwater and soils, the $\mathrm{Cl}$ signature in tree cores is unlikely to provide information on the timing of HVOC uptake. When there is substantial underground dechlorination within the capture zone of the root system, however, it is likely that the groundwater $\mathrm{Cl}$ signature would overwhelm in-tree 
effects and would predominantly be located in the growth ring corresponding to the year of uptake. In the tree cores examined at Verl, there was no distinctive change in $\mathrm{Cl}$ chemistry from one side of the heartwood/sapwood boundary to the other, implying that there was no significant translocation across the boundary, as is sometimes seen for translocated elements. ${ }^{25}$

\section{RESULTS AND DISCUSSION}

The EDXRF procedure allows for the direct comparison of two or more elements at once (Figures 3 and 4). Bielemental

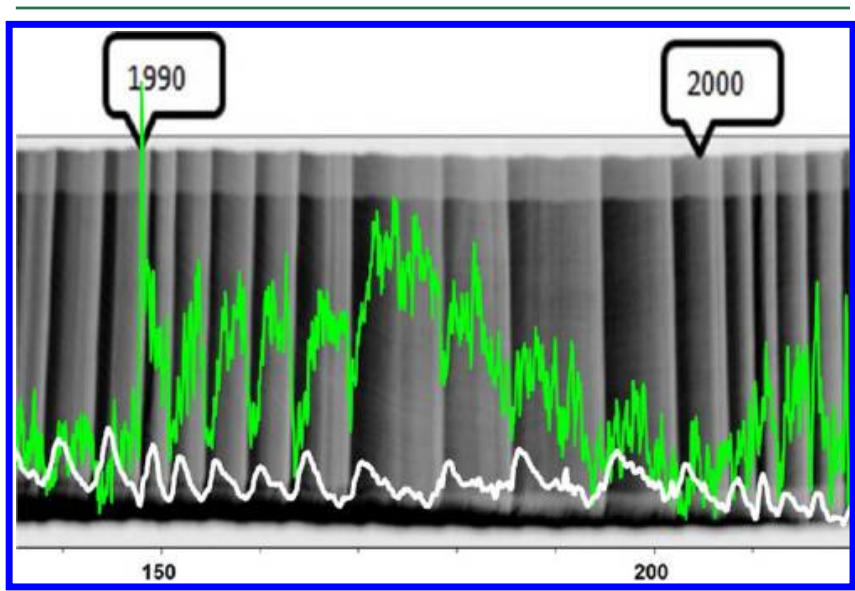

Figure 3. Relative concentrations of chlorine (green) and calcium (white) determined by energy-dispersive $\mathrm{X}$-ray fluorescence overlaid on an X-ray image of the tree 7 core (Verl, Germany). Also, note that, at the 1990/1991 rings, the $\mathrm{Cl}$ impact occurred during the period of late wood formation, as evidenced by the peak having its highest amplitude in the 1990 late wood, and the subsequent early wood recorded a $\mathrm{Cl}$ minima significantly higher than in previous rings. Note the characteristic annual, intra-ring patterns, often showing the lowest $\mathrm{Cl}$ concentrations in the early wood.

profiles for $\mathrm{Ca}$ (in white) and $\mathrm{Cl}$ (in green) are superimposed on an X-ray image of the core from tree 7 (Figure 3 ). The direction of growth is from left to right, with the transition between annual growth rings marked by the contrast between the more physically dense late wood (light-colored in the X-ray image) and the less dense early wood of the following year (dark-colored in the $\mathrm{X}$-ray image). Note the characteristic annual, intra-ring patterns of $\mathrm{Cl}$, which usually are at their lowest during the early wood growth period, or the summer. The Cl-only anomalies are interpreted as being associated with the chlorinated solvent plume. Also, in the 1990/1991 rings of tree 7 , the $\mathrm{Cl}$ uptake appears to have occurred during the late wood growth period. Consistent with this interpretation, the minimum $\mathrm{Cl}$ concentration in the susbsequent early wood growth period was substantially higher than in previous rings (Figure 3).

EDXRF shows distinct bielemental anomalies for $\mathrm{Ca}$ and $\mathrm{Cl}$ in tree 2 (Figure 4), peaking in 1908, 1918, 1931, and 1976. The dual $\mathrm{Ca}$ and $\mathrm{Cl}$ signature was interpreted as possibly being the result of drought or other climatic influences not related to contamination; the 1976 drought had a similar $\mathrm{Ca} / \mathrm{Cl}$ signature in tree 2 as the three earlier anomalies. Tree 2 also shows four to five asynchronous Cl-only impacts (Table 1), potentially indicating the presence of HVOCs. ${ }^{8,9,12}$ The $1948 / 1949 \mathrm{Cl}$ peak in tree 2 does not have a directly corresponding Ca peak, but there are other $\mathrm{Ca}$ anomalies in close proximity (Figure 4), imparting some level of uncertainty as to whether this was a Clonly event. It is of interest, however, that, while searching for a potential cause of the $1948 / 1949 \mathrm{Cl}$ anomaly in tree 2, investigators found that the industrial plant had been active since 1945 and that two buildings containing PCE were destroyed in 1948 and on April 22, 1949, potentially resulting in a contamination release.

It is highly likely that the chemistry in tree 2 is influenced by groundwater chemistry because the depth to groundwater at tree 2 is only about $50 \mathrm{~cm} . \mathrm{Cl}$ anomalies in tree 2 are present in growth rings from two years that the PCE-containing buildings were destroyed and might represent HVOCs related to those events. If so, then the HVOCs would have been rapidly transported from the source area to tree 2. A potential explanation for rapid transport of HVOCs is that they could have moved by overland flow through a drainage ditch or creek. There is, in fact, the remnant of a former ditch or stream near trees 1 and 2, over $15 \mathrm{~m}$ in length and oriented in the direction of groundwater flow (the ditch is shown in the background of Figure 2). Construction and landscaping have eliminated much of the stream and obscured its original path; however, proximity to trees 1 and 2 and orientation in the direction toward the source area imply the possibility that the ditch once provided surface drainage from the source area to the vicinity of tree 2. The subsequent $\mathrm{Cl}$ anomaly in tree 2, 11-12 years later (1960/1961), could potentially be explained by groundwater transport of contamination and delayed impact from the same 1948 and 1949 releases. Modeling simulations (MODFLOW) produced time-of-travel estimates consistent with groundwater transport of contaminants to the four trees at dates corresponding to the $\mathrm{Cl}$ anomalies (see Figure 5).

Trees 5-7 also show, depending on their age and location, a minimum of two to four asynchronous $\mathrm{Cl}$ anomalies (Figures 5 and 6). Potentially, the anomalies might represent the transport

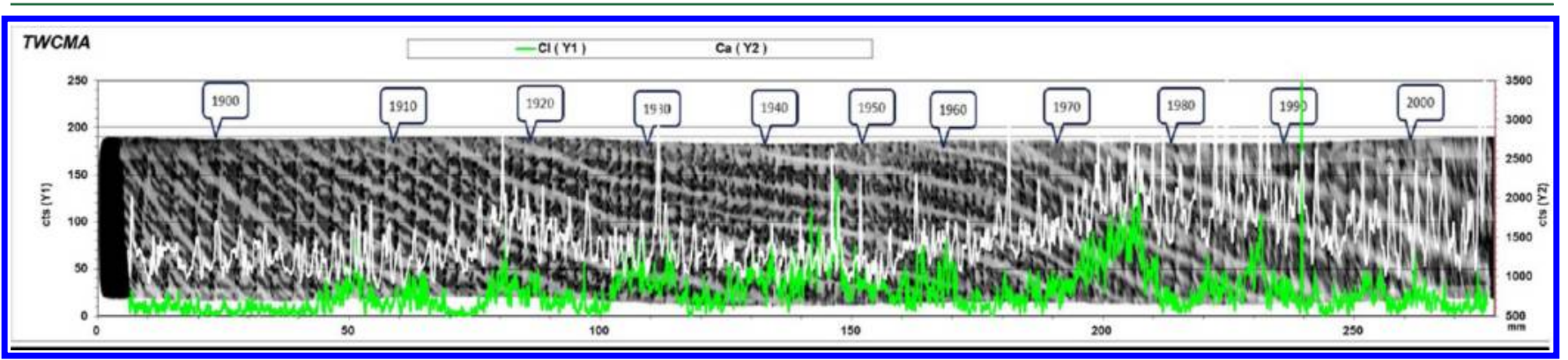

Figure 4. Detail of bielemental profiles for $\mathrm{Ca}$ in white and $\mathrm{Cl}$ in green, superimposed on an $\mathrm{X}$-ray image of the tree 2 core. The direction of growth is from left to right, expressed by the transition from dark early wood (with low density) to light late wood (with high density). The chlorine-only anomalies are interpreted as a potential response to a chlorinated solvent plume. 


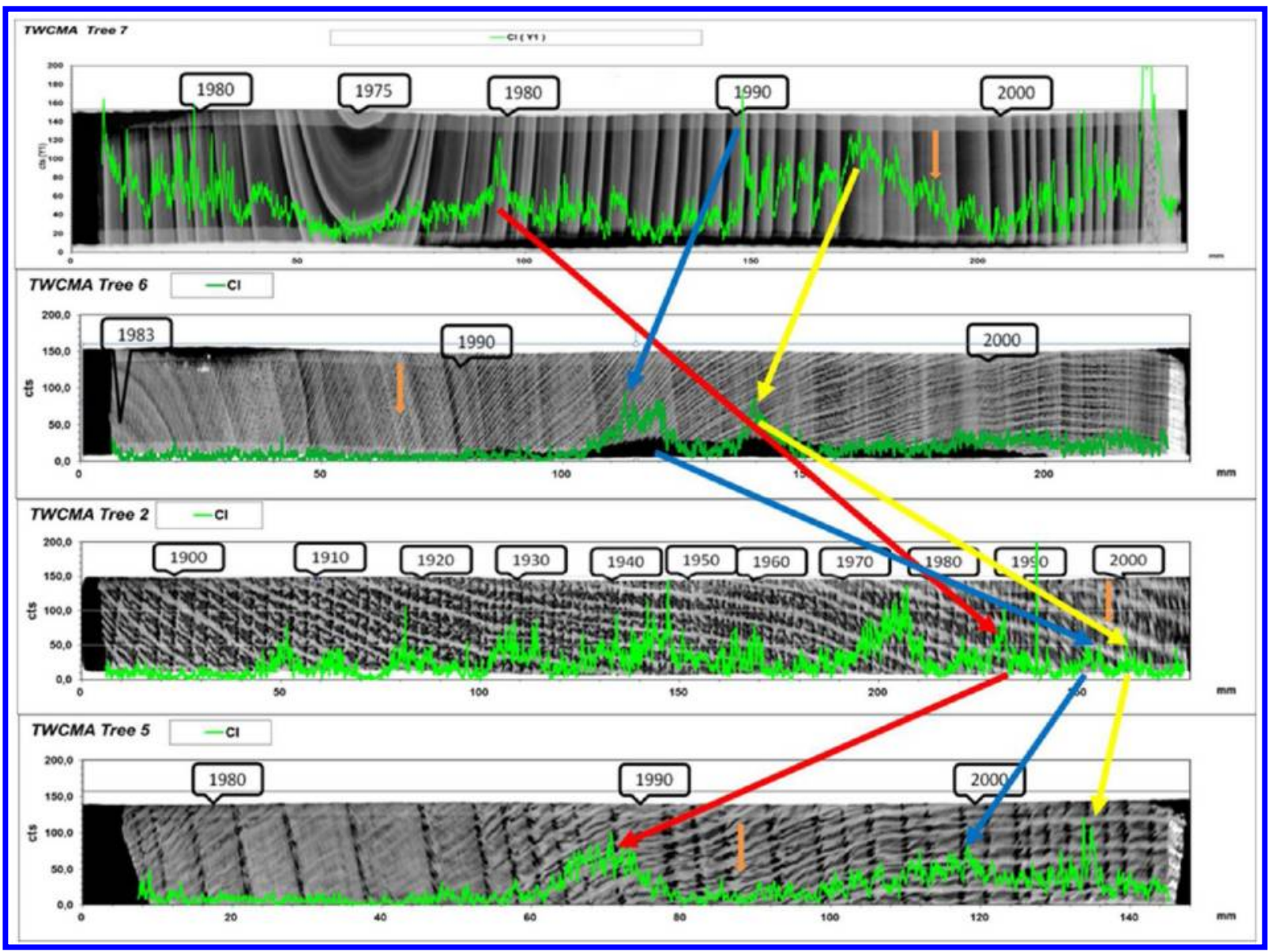

Figure 5. EDXRF data for the four analyzed cores from Verl, Germany, showing elemental profiles for Cl. They correspond, from top to bottom, to trees 7, 6, 2, and 5 and are listed in order of their distance from the plume. The red, blue, and yellow lines correspond to interpreted events B, C, and D, respectively, in Table 2 . Note that tree 2 is the only tree old enough to have reflected potential releases identified from 1948/1949 and the subsequent 1960/1961 impact via groundwater; tree 6 is too recent to show the impact found in tree 7 in 1980 and later found in trees 2 and 5 (red arrow). The recent $2004 \mathrm{Cl}$ anomaly found in tree 7 would not have impacted tree 6 in 2010. The orange arrows represent the location of the heartwood/sapwood boundary (HSB). The lack of a distinctive change in $\mathrm{Cl}$ concentrations across the HSB provides evidence that there is no significant chlorine lateral translocation in these trees.

of additional releases of contaminants. Trees 5 and 6 are at the edge of the present groundwater plume boundary (Figure 1); however, the historical extent of contamination might have been different than what is now present. Knowledge of groundwater and potential contamination sources and events is needed to provide corroborating lines of evidence.

Measured groundwater flow rates and model (MODFLOW) estimated plume migration rates (consulting firm HPC Envirotec, written communication, 2010) showed the probable plume migration rate to be about $20-30 \mathrm{~m} /$ year in the southern part and 2-3 times higher in the northern part of the plume. The plume migration rate, as estimated from a comparison of $\mathrm{Cl}$ anomalies in trees to the distance separating the trees, was about $30 \mathrm{~m} /$ year in the southern part of the plume and 70-120 m/year toward the northern half of the plume. The average plume migration rate based on the tree cores was about $54 \mathrm{~m} /$ year over the $820 \mathrm{~m}$ separating the source from the most distant tree, tree 5 (see Figure 6). The close agreement between the estimates of the plume migration rate supports the hypothesis that the $\mathrm{Cl}$ anomalies represent movement of groundwater contamination. Agreement between model-derived and tree-chemistry-derived groundwater flow rates wasalso observed in a previous study. ${ }^{26}$
It should be noted that there are uncertainties in both the groundwater- and tree-derived estimates of contaminant transport. The uncertainties in the groundwater-derived estimates involve uncertainties in both modeling formulations and porosity estimates, particularly in these heterogeneous glacial deposits. Uncertainties in the tree-derived estimates involve a possible half-year lag time during the nongrowing season when a dendrochemical signal might not be effectively recorded. If, however, dendrochemical signals can be shown to be a reasonable estimate of contaminant arrival dates for a particular site, then the information could have great supportive value as a complementary approach for estimating contaminant transport rates.

The black, red, blue, and yellow lines in Figures 5 and 6 identify the potential asynchronous releases of $\mathrm{Cl}$, labeled A-E, respectively, and correspond to the suspected releases listed in Table 2. Based on the plume migration rates through groundwater estimated from the dendrochemical record and the distance between the southernmost trees and those closest to the source and historical records, the timing of the releases were estimated to be 1948-1949 (release A), 1975 (release B), 1985 (release C), 1990 (release D), and 1999 (release E), as reported in Table 2. Releases that took place after industry ceased its production activities in 1969 might be associated with 


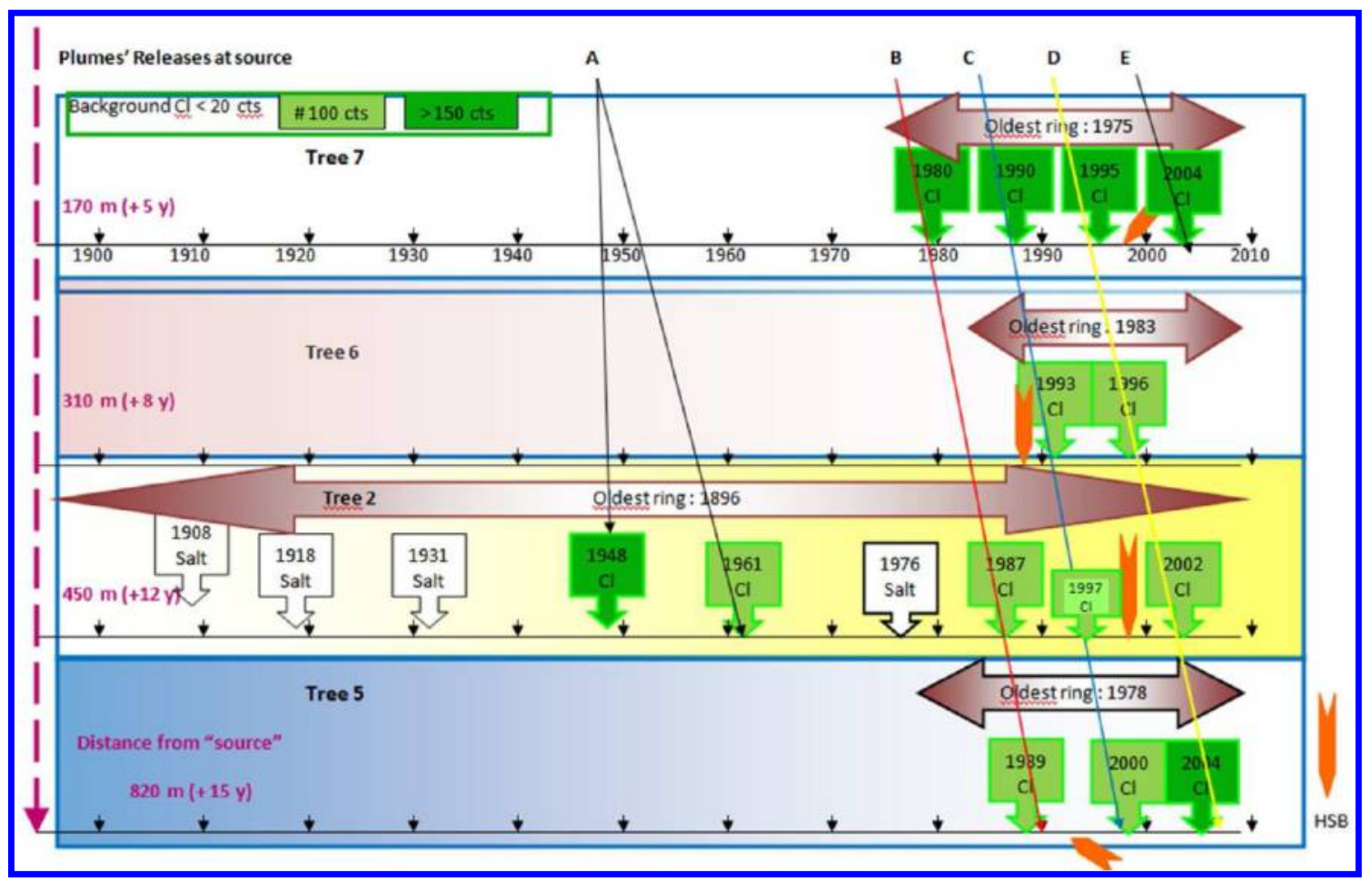

Figure 6. Interpretation of the contaminant releases at source, plume migration, and impact times, based on the parsimony principle. The scenarios show five potential asynchronous releases impacting the four trees within the time needed for the plume to migrate from the source to each tree. The left vertical arrow shows the plume migration direction, with distance from the source; the four cores are arranged by proximity to the source. The connecting lines correspond to the interpreted events in Table 2. The colors of the descriptive boxes represent the analytical response in counts (cts). The term "salt" is used for coincident $\mathrm{Ca}$ and $\mathrm{Cl}$ anomalies observed in tree 2. Orange arrows show the location of the heartwood/sapwood boundary (HSB).

Table 2. Estimated Times of Pollutant Releases at the Site in Verl, Germany

$\begin{array}{cc}\text { plume } & \text { time of contaminant release } \\ \text { A } & 1948,1949 \\ \text { B } & 1975 \\ \text { C } & 1985 \\ \text { D } & 1990 \\ \text { E } & 1999\end{array}$

progressive plant dismantling and remediation activities or with activities at a garage shop that began operation in 1980 .

The data provided herein demonstrate that the high resolution of the EDXRF method allows comparisons of wood chemistry at a scale that can differentiate changes within a single growth ring. The data can be used to examine the timing of environmental events with approximately annual precision. Although the past can never be reconstructed with complete accuracy, the Verl study area shows the potential of dendrochemical methods to indicate multiple historical and asynchronous environmental impacts to trees, along with corresponding plume migration rates, and to age-date releases from the source. The combination of the dendrochemical data obtained using today's methodologies, available information on historical activities at the industrial locations, and groundwater modeling data potentially can be used to project back possible scenarios of events that occurred in the past.

\section{AUTHOR INFORMATION}

\section{Corresponding Author}

*Phone: +33344397312; e-mail: balouet.jean-christophe@neuf. fr.

\section{Notes}

The authors declare no competing financial interest.

\section{ACKNOWLEDGMENTS}

The site investigation was funded by HPC Envirotec R\&D division. Field, premapping, and important historical research were conducted by Ralf Sutka, HPC Envirotec AG. We are also deeply indebted to PIT (Pollution Investigation by Trees), an international program funded by Ademe (French Agence de l'Environnement et de la Maitrise de l'Energie). We are also indebted to James Landmeyer of the U.S. Geological Survey and the many others who contributed to the review of this article. The use of trade names in this document does not imply endorsement on the part of the organizations represented by the authors or by the U.S. Government.

\section{REFERENCES}

(1) Schweingruber, F. H. Tree Rings and Environment: Dendroecology; Swiss Federal Institute for Forest, Snow and Landscape Research and Paul Haupt Verlag.: Bern, Switzerland, 1996.

(2) Smith, K. T. An organismal view of dendrochronology. Dendrochronologia 2008, 26 (3), 185-193.

(3) Briand, C. H.; Brazer, S. E.; Harter-Dennis, J. M. Tree rings and the aging of trees: A controversy in 19th century America. Tree-Ring Res. 2006, 62 (2), 51-65. 
(4) da Vinci, L. Treatise on Painting (Codex Urbinas Latinus 1270); McMahon, A. P., Translator; Princeton University Press: Princeton, NJ, 1956.

(5) Speer, J. Fundamentals of Tree-Ring Research; The University of Arizona Press: Tucson, AZ, 2010.

(6) Chiment, V. J.; Chiment, J. J. Analytic bibliography of basic and applied dendrochemistry. Simple Interest 2005, 1, 11-28.

(7) Smith, K. T.; Shortle, W. C. Tree biology and dendrochemistry. In Tree Rings, Environment and Humanity. Proceedings of an International Conference; Dean, J. S.; Meko, D. M.; Swetnam, T. W., Eds.; Radiocarbon: Tucson, AZ, 1996; pp 629-635.

(8) Balouet, J.-C.; Oudijk, G.; Petrisor, I.; Morrison, R. D. Emerging Forensic Techniques. In Introduction to Environmental Forensics, 2nd ed.; Murphy, B. L.; Morrison, R. D., Eds.; Academic Press: New York, 2007; Chapter 15, pp 671-731, XLII-XLVI.

(9) Balouet, J. C.; Smith, K. T.; Vroblesky, D.; Oudijk, G. Use of dendrochronology and dendrochemistry in environmental forensics: Does it meet the Daubert criteria? Environ. Forensics 2009, 10 (4), $268-276$.

(10) Burken, J. G.; Vroblesky, D. A.; Balouet, J. C. Phytoforensics, Dendrochemistry, and Phytoscreening: New Green Tools for Delineating Contaminants from Past and Present. Environ. Sci. Technol. 2011, 45 (15), 6218-6226.

(11) Vroblesky, D. User's Guide to the Collection and Analysis of Tree Cores to Assess the Distribution of Subsurface Volatile Organic Compounds; USGS Scientific Investigations Report 2008-5088; U.S. Geological Survey: Washington, DC, 2008.

(12) Balouet, J. C.; Oudijk, G.; Smith, K. T.; Petrisor, I.; Grudd, H.; Stocklassa, B. Applied dendroecology and environmental forensics. Characterizing and age dating environmental releases: Fundamentals and case studies. Environ. Forensics 2007, 8 (1-2), 1-17.

(13) Cutter, B. E.; Guyette, R. P. Anatomical, Chemical, and Ecological Factors Affecting Tree Species Choice in Dendrochemistry Studies. J. Environ. Qual. 1993, 22 (3), 611-619.

(14) Limmer, M. A.; Balouet, J. C.; Karg, F.; Vroblesky, D. A.; Burken, J. G. Phytoscreening for Chlorinated Solvents Using Rapid in Vitro SPME Sampling: Application to Urban Plume in Verl, Germany. Environ. Sci. Technol. 2011, 45 (19), 8276-8282.

(15) Lindeberg, J. X-ray based tree ring analyses. Doctoral Thesis, Swedish University of Agricultural Sciences, Umeå, Sweden, 2004.

(16) DeWalle, D. R.; Tepp, J. S.; Swistock, B. R.; Sharpe, W. E.; Edwards, P. J. Tree-ring cation response to experimental watershed acidification in West Virginia and Maine. J. Environ. Qual. 1999, 28 (1), 299-309.

(17) DeWalle, D. R.; Sharpe, W. E.; Swistock, B. R. Oak Bole-Wood Chemistry Response to Fertilization at Two Ozark Sites; General Technical Report SRS-73; Southern Research Station, Forest Service, U.S. Department of Agriculture: Asheville, NC, 2004; pp 297-298.

(18) Wiedemeier, T. H.; Rifai, H. S., Newell, C. J., Wilson, J. T. Natural Attenuation of Fuels and Chlorinated Solvents in the Subsurface; Wiley: New York, 1999.

(19) Yanosky, T. M.; Hansen, B. P.; Schening, M. R. Use of tree rings to investigate the onset of contamination of a shallow aquifer by chlorinated hydrocarbons. J. Contam. Hydrol. 2001, 50 (3-4), 159173.

(20) Baduru, K. K.; Trapp, S. T.; Burken, J. G. Direct Measurement of VOC Diffusivities in Tree Tissues: Impacts on Tree-Based Phytoremediation. Environ. Sci. Technol. 2008, 42 (4), 1268-1275.

(21) Ma, X.; Burken, J. G. Diffusion of TCE to the Atmosphere in Phytoremediation Applications. Environ. Sci. Technol. 2003, 37 (11), 2534-2539.

(22) Graber, E. R.; Sorek, A.; Tsechansky, L.; Atzmon, N. Competitive Uptake of Trichloroethene and 1,1,1-Trichloroethane by Eucalyptus camaldulensis Seedlings and Wood. Environ. Sci. Technol. 2007, 41 (19), 6704-6710.

(23) Newman, L. A.; Strand, S. E.; Choe, N.; Duffy, J.; Ekuan, G.; Ruszaj, M.; Shurtleff, B. B.; Wilmoth, J.; Heilman, P.; Gordon, M. P. Uptake and biotransformation of trichloroethylene by hybrid poplars. Environ. Sci. Technol. 1997, 31 (4), 1062-1067.
(24) Vroblesky, D. A.; Clinton, B. D.; Vose, J. M.; Casey, C. C.; Harvey, G. J.; Bradley, P. M. Groundwater chlorinated ethenes in tree trunks: Case studies, influence of recharge, and potential degradation mechanism. Ground Water Monit. Rem. 2004, 24 (3), 124-138.

(25) Vroblesky, D. A.; Yanosky, T. M.; Siegel, F. R. Increased Concentrations of Potassium in Heartwood of Trees in Response to Groundwater Contamination. Environ. Geol. Water Sci. 1992, 19 (2), $71-74$.

(26) Vroblesky, D. A.; Yanosky, T. M. Use of tree-ring chemistry to document historical ground-water contamination events. Ground Water 1990, 28 (5), 677-684. 